\title{
Breast Lymphoma
}

National Cancer Institute

\section{Source}

National Cancer Institute. Breast Lymphoma. NCI Thesaurus. Code C4671.

A lymphoma that arises from the breast. There is no history of extramammary breast lymphoma and ipsilateral axillary lymph node involvement does not exclude the diagnosis of primary breast lymphoma. Most patients present with a painless breast lump. The vast majority of cases are B-cell non-Hodgkin lymphomas. Diffuse large B-cell lymphoma, follicular lymphoma, and extranodal marginal zone B-cell lymphoma of mucosa associated lymphoid tissue are the most common types of primary nonHodgkin lymphoma of the breast. Primary Hodgkin lymphoma of the breast is rare. 